\title{
SAGITTAL BALANCE AFTER POSTERIOR INSTRUMENTATION IN LUMBAR FRACTURES
}

\author{
EQUILÍBRIO SAGITAL APÓS A INSTRUMENTAÇÃO POSTERIOR EM FRATURAS LOMBARES
}

\author{
BALANCE SAGITAL DESPUÉS DE LA INSTRUMENTACIÓN POSTERIOR EN \\ FRACTURAS LUMBARES
}

\author{
luis Muñiz luna', Fernando Guevara Villazón², José Enrique Salcedo Oviedo², Iván Omar Cáliz Castorena² \\ 1. "Hospital deTraumatología y Ortopedia Lomas Verdes", Edo. de México Poniente, Instituto Mexicano del Seguro Social, Mexico. \\ 2. UMAE HTOLV, IMSS, Mexico.
}

\begin{abstract}
Objective: When a lumbar fractures developes a significant deformity, the sagittal balance is altered which can lead to clinical consequences. The aim of this study was to measure and analyze the sagittal balance in patients with lumbar fractures operated with posterior instrumentation after three months and analyze their correlation with the different variables of the patient and the fracture. Methods: Sixty-three medical records of patients with lumbar fracture operated with posterior instrumentation were analyzed, excluding those with previous spinal pathology, or inability to stand upright. The parameters of pelvic incidence, sacral slope, pelvic tilt, lumbar lordosis, lumbar lordosis/pelvic incidence (LL/ $\mathrm{PI}$ ) ratio, as well as the pre and postoperative status of segmental kyphosis and residual pain were measured. Results: Eighteen women, 44 men, with mean age of 42 years, with lumbar fractures: 29 in L1, 19 in L2, 10 in L3, 3 in L4 and 1 in L5. AOSpine Clasification: 2 type A1, 2 type A2, 37 type A3, 19 type A4, 2 type B. All patients were operated with a transpedicular polyaxial system. More than 80\% of patients with spinopelvic balance within parameters considered normal. More than $70 \%$ with lumbar lordosis and LL/PI ratio within parameters. All with improvement of segmental kyphosis (average correction of $8.5^{\circ}, \mathrm{p}<.000$ ). Final mean VAS of 1.85. Conclusions: The posterior instrumentation with a polyaxial system allows acceptable corrections of the segmental kyphosis of lumbar fractures. No statistically significant correlation was found between sagittal balance parameters, and characteristics of the patient and fracture. Level of Evidence IV; Case series.
\end{abstract}

Keywords: Spinal fractures; Postural balance; Instrumentation.

\section{RESUMO}

Objetivo: Quando uma fratura lombar evolui com deformidade significativa, o equilibrio sagital é alterado, o que pode levar a consequências da manifestação clínica. O objetivo deste estudo foi mensurar e analisar o equilíbrio sagital em pacientes com fratura lombar operada com instrumentação, após três meses, analizando sua correlação com as diferentes variáveis do paciente e da fratura. Método: Foram analisados 63 casos de pacientes com fratura lombar, operados com instrumentação posterior, excluindo-se aqueles com patologia anterior da coluna vertebral ou incapacidade de se manter em pé, parâmetros de incidência pélvico, sacro inclinação, a inclinação da pelve, lordose lombar, relação lordose lombarlincidência pélvica (LL / IP) e a cifose segmentar pós-operatória e pré estado da dor residual mensuradas. Resultados: 18 mulheres, 44 homens, idade média dos pacientes: 42 anos, fraturas: $29 \mathrm{em} \mathrm{L1,} 19 \mathrm{em} \mathrm{L2,} 10 \mathrm{em} \mathrm{L3,} 3 \mathrm{em} \mathrm{L4} \mathrm{e} 1$ em L5. AOSPINE: 2 tipo A1, 2 tipo A2, 37 tipo A3, 19 tipo A4, 2 tipo B. Todos operados com sistema poliaxial transpedicular. $>80 \%$ dos pacientes com balanço espinopélvico, dentro de parâmetros considerados normais. $>70 \%$ com lordose lombar e relação LL / IP dentro dos parâmetros. Todos com melhora da cifose segmentar (correção média de 8,5, $p<0,000$ ). EVA final médio de 1,85. Conclusão: Instrumentação posterior com um sistema poliaxial permite correções aceitáveis da cifose segmentar das fraturas lombares. Não houve correlação estatisticamente significativa encontrada entre os parâmetros de equilíbrio sagital e as características do paciente e da fratura. Nível de Evidência IV; Série de casos.

Descritores: Fraturas da coluna vertebral; Equilíbrio postural; Instrumentação.

\section{RESUMEN}

Objetivo: Cuando una fractura lumbar evoluciona con una deformidad significativa, se ve alterado el balance sagital lo cual puede llevar a consecuencias clínicas. El objetivo de este estudio fue medir y analizar el balance sagital en pacientes con fracturas lumbares operados con instrumentación posterior después de tres meses y analizar su correlación con las diferentes variables del paciente y la fractura. Métodos: Se analizaron 63 expedientes de pacientes con fractura lumbar operados con instrumentación posterior excluyendo aquellos con patología previa de columna, o incapacidad para bipedestación. Se midieron los parámetros de incidencia pélvica, pendiente sacra, inclinación pélvica, lordosis lumbar, relación lordosis lumbarlincidencia pélvica (LL/IP), así como el estado pre y postoperatorio de la cifosis segmentaria y el dolor residual. Resultados: Dieciocho mujeres, 44 hombres, con edad promedio de 42 años con fracturas lumbares: 29 en L1, 19 en L2, 10 en L3, 3 en L4 y 1 en L5. Clasificación AOSPINE: 2 tipo A1, 2 tipo A2, 37 tipo A3, 19 tipo A4, 2 tipo B. Todos los pacientes fueron operados con sistema poliaxial transpedicular. Más del 80\% de los pacientes con balance espinopélvico dentro de parámetros considerados normales. Más del 70\% con lordosis lumbar y relación LL/IP dentro de los parámetros. Todos con mejoría de la cifosis segmentaria (corrección promedio de 8,5, $p<0.000$ ). EVA final promedio de 1,85. Conclusiones: La instrumentación posterior con un sistema poliaxial permite correcciones aceptables de la cifosis segmentaria de las fracturas lumbares. No se encontró correlación estadísticamente significativa entre los parámetros de balance sagital y las características del paciente y la fractura. Nivel de Evidencia IV; Serie de casos.

Descriptores: Fracturas de la columna vertebral; Balance postural; Instrumentación. 


\section{INTRODUCTION}

Sagittal balance reflects the morphology of the spino-pelvic segment that permits standing. A change in sagittal balance translates into a mechanical alteration that modifies the way in which forces are balanced by the anatomical elements to keep the trunk erect. Degenerative structural changes and overuse of the muscle masses are expected to produce pain, neurological deficit, and deformity. The main causes of sagittal imbalance are those related to childhood deformities and iatrogenic and posttraumatic adult deformities. ${ }^{1,2}$

Lumbar fractures are a cause of sagital imbalance and can evolve with posttraumatic kyphosis as a sequela. The principles of the AOSPINE classification can be used to guide decision making about how to manage them. ${ }^{3}$ Other characteristics of thoracolumbar fractures used to guide treatment decisions are segmental kyphosis and vertebral body collapse, with segmental kyphosis greater than $20^{\circ}$ and collapse greater than $50 \%$ considered to be instability. Surgical treatment is planned to address the needs of the fracture of each patient. The main objectives are stabilization of the affected segment(s), decompression in the case of the coexistence of neurological deficit secondary to intraradicular compression from bone fragments, and recovery and maintenance of sagittal balance by reducing the segmental kyphosis of the fractured segment, thus recovering lumbar lordosis. The current options are many. Among the most used are vertebral instrumentation with transpedicular systems using Schanz nails, monoaxial and/or polyaxial screws connected by steel, titanium, or cobalt chrome rods, and when necessary, achieving decompression of the neural elements of the spinal canal via laminectomy and/or corpectomy, depending on the case, plus vertebral reconstruction with implants that replace the vertebral body such as simple meshes or telescopic cages. ${ }^{4}$

The functional recovery of the physiological curves of the spine prevents functional sequelae that can result in a high degree of physical disability due to the presence and/or persistence of low back pain, kyphotic deformity, and in some cases can be serious when associated with a progressive neurological deficit that is manifested as a loss of control of the urethral and anal sphincters and of strength and sensitivity in the lower limbs, among others.

Anatomical and mechanical studies have proposed several relationships between the spino-pelvic parameters and lumbar lordosis. Pelvic incidence helps to determine the normality of the lumbar lordosis, which is estimated to have a similarity of $+/-10^{\circ}$. Pelvic tilt and sacral slope (Figure 1) define pelvic anteversion and, therefore, are determined, among other things, by lumbar lordosis. When they are altered, flexion of the lower limbs is manifested to maintain the standing position. 5,6

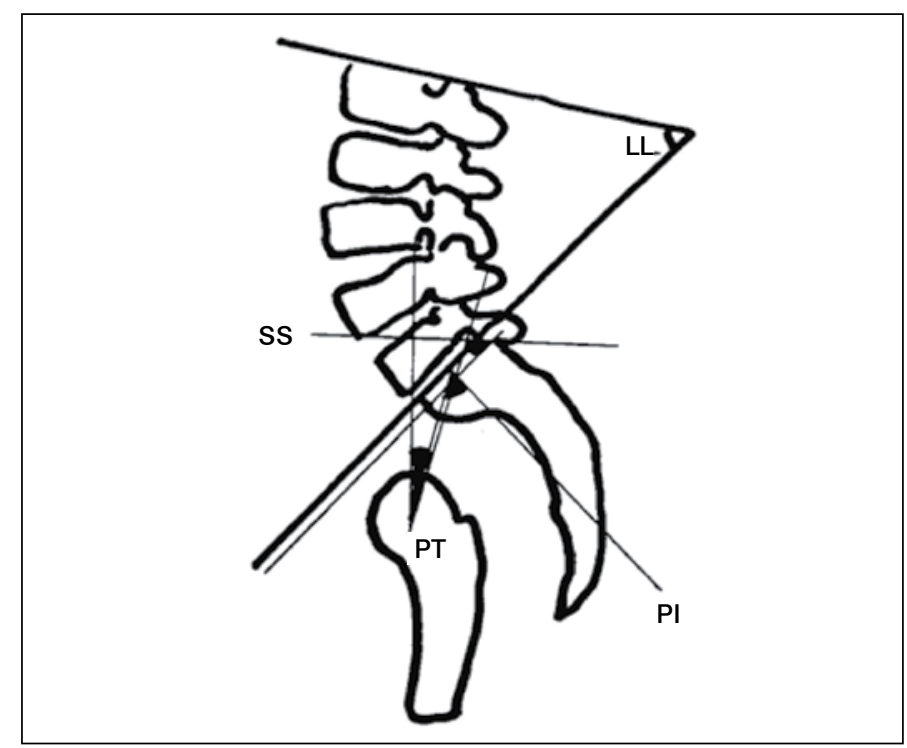

Figure 1. Spino-pelvic Parameters (LL lumbar lordosis, SS sacral slope, PT pelvic tilt, PI pelvic incidence).
Sagittal balance can be measured using different parameters. The C7 plumb line is measured with a vertical axis at C7 and its distance from the posterior edge of the promontory. Pelvic incidence is a fixed parameter that measures the angle between the promontory and the center of the femoral head, measuring on average between $34^{\circ}$ and $84^{\circ}$. Sacral slope is the angle between the promontory and the horizontal axis. It averages $40^{\circ}$ with a range from $20^{\circ}$ to $65^{\circ}$. Pelvic tilt is measured by the angle from the center of the femoral heads in the vertical axis and the center of the promontory. Pelvic incidence is equal to the sum of the angles of pelvic inclination and sacral slope..$^{7-9}$

Posttraumatic kyphosis is defined as any spinal deformity with anterior concavity secondary to a spinal injury with the collapse of one or several vertebral bodies or failure of the tension band. In the lumbar spine, posttraumatic kyphosis reduces lumbar lordosis and alters sagittal balance, which can produce symptoms like pain, neurological deficit, and visible deformity. Suggested indications for surgery are sagittal imbalance accompanied with claudication, segmental kyphosis greater than $20^{\circ}$ with symptology resistant to conservative treatment and progressive deformity. The main treatment is carried out performing corrections to the deformity based on osteotomies and instrumentation. ${ }^{10,11}$

The objective of this study was to measure and analyze the sagittal balance parameters in patients with acute traumatic lumbar fractures treated surgically with posterior instrumentation.

\section{METHODS}

This was an observational, longitudinal, retrospective study of a case series, authorized by the Institutional Review Board no. R-20171501-31, in which we analyzed the medical and radiographic records of 63 patients diagnosed with acute traumatic lumbar fractures treated surgically with posterior instrumentation and who were followed-up postoperatively for a minimum of three months. All the procedures were performed by spine surgeons of the Spine Surgery Service of the "Hospital de Traumatología y Ortopedia Lomas Verdes" High Specialty Medical Unit of the IMSS. All medical records of patients with the diagnosis and treatment described (Figure 2) and who had lateral lumbar radiographs taken in a neutral standing position with the acetabular domes visible were included. Patients who were unable to stand and/or walk or who had undergone prior spinal or pelvic surgeries were excluded. Cases with pathological and/or metabolic fractures or with multiple spinal fractures were not included.

All the cases had a radiological study that included a lateral lumbopelvic projection of the patient in a neutral standing position in

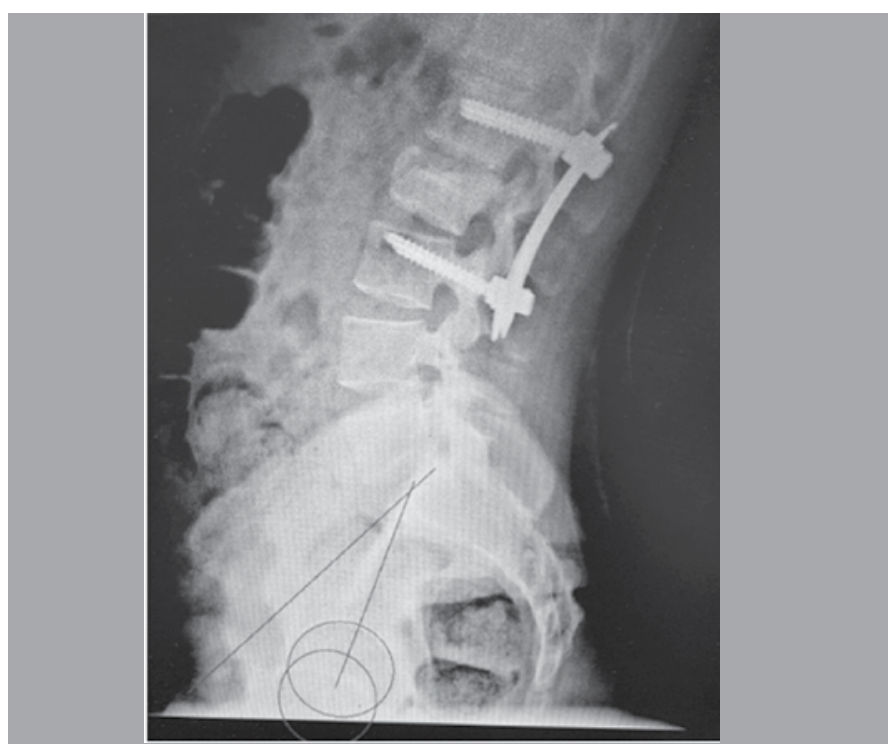

Figure 2. Radiograph of a clinical case with lumbar fracture and posterior instrumentation using a polyaxial transpedicular system. 
which the section from T11 to the femoral heads could be seen. Radiographic measurements were taken with the WebServex system (Radiología de México) in multi-observer mode and with the SagittalMeter Pro Version 1.0.246 measurement tool. The parameters of pelvic incidence, sacral slope, pelvic tilt, lumbar lordosis, and L4-S1 lordosis were measured. The traumatic deformity of each segment, the segmental kyphosis, was measured before and after surgery. It is important to mention that it was not possible to obtain reliable sagittal balance in some preoperative studies since there were cases in which standing was contraindicated by the type of fracture and those studies were evaluated in supine decubitus. We also evaluated the visual analog scale for pain (VAS) according to the medical records.

The size of our sample was by convenience, however, it satisfied the calculation for sample size for the known statistic, with a confidence level of $95 \%$ and a margin of error of $10 \%$. A non-parametric Kolmogorov-Smirnov test was also performed to determine normality in the distribution of the variables in the population.

We conducted a statistical analysis by first denoting the normality of the sample distribution with Kolmogorov-Smirnov and then looking for the correlation coefficient between the patient's own variables, the fracture, and the sagittal balance with the Pearson test. In addition, we conducted the Wilcoxon signed-rank test to determine the pre- to postoperative improvement of the segmental kyphosis with surgical treatment. The statistical tests were performed with the software SPSS Statistics (version 23, IBM) and were considered statistically significant for $\mathrm{p}<.05$.

\section{RESULTS}

We studied 63 medical records of patients with lumbar fractures treated surgically with posterior instrumentation and with a minimum of three months of postoperative follow-up. There were 18 women and 45 men with an average age of 43 years (16-72).

Sixty-three fractures were recorded, 30 in L1, 19 in L2, 10 in L3, 3 in L4, and 1 in L5. They were classified according to the AOSpine system resulting in 2 of type $A 1,2$ of type $A 2,38$ of type $A 3,19$ of type A4, and two of type B (1 type B1 and 1 type B2). All were instrumented with a system of polyaxial transpedicle screws, 46 with a single level above and a single level below and 17 with more instrumented levels, most of them with two levels above and two below. (Figures 3, 4)

The spino-pelvic parameters found were: average pelvic incidence of $47^{\circ}\left(74^{\circ}-24^{\circ}\right)$, pelvic tilt of $13^{\circ}\left(30^{\circ}-1^{\circ}\right)$, sacral slope of $33^{\circ}\left(52^{\circ}-6^{\circ}\right)$, lumbar lordosis of $48^{\circ}\left(78^{\circ}-25^{\circ}\right)$, L4-S1 lordosis of $37^{\circ}\left(63^{\circ}-17^{\circ}\right)$, and segmental kyphosis of $0.3^{\circ}(-13-19)$.

The average VAS for pain at discharge was 1.85. There were six patients with VAS for pain higher than five, who continued to be managed in rehabilitation. There were four patients with infection of the surgical wound, two of whom responded to antibiotic treatment and two of whom required removal of the osteosynthesis material. In one patient, the material was removed because of loosening of the osteosynthesis

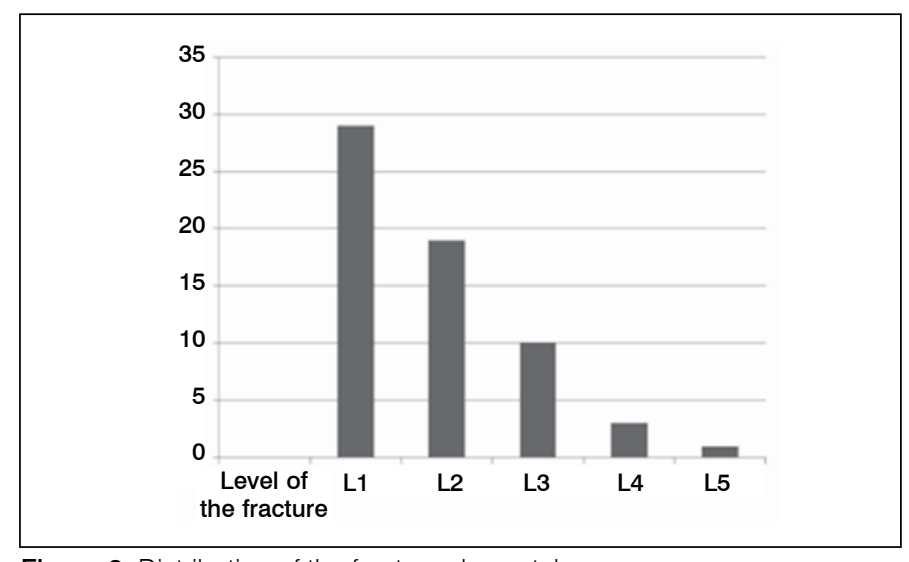

Figure 3. Distribution of the fractures by vertebra. material during consolidation of the fracture. Four patients with ASIA D evolved with complications of constipation and urinary incontinence.

The percentages of the spino-pelvic parameters within the ranges reported in the literature were pelvic incidence $87 \%$, pelvic tilt $83 \%$, sacral slope 95\%, lumbar lordosis 73\%, and L4-S1 lordosis $60 \%$. The pelvic incidence/lumbar lordosis ratio was within the normal parameters in $71 \%$ of the patients. The lumbar lordosis/ L4-S1 lordosis ratio using the rule of $2 / 3$ was reported in $73 \%$ of the patients. (Tables 1, 2)

In the statistical analysis, we found normality in the distribution of the variables using the Kolmogorov-Smirnov test ( $p>.05)$. In the Pearson correlation tests no statistically significant relationship was found between the spino-pelvic parameters and age, sex, level fractured, residual pain, altered neurological status, infections, AOSpine classification, segmental kyphosis, or length of the instrumentation. The relationships found were discarded in the interest of logical correlation or lack of statistical significance (e.g. Greater segmental kyphosis at lower levels L4-L5). The Wilcoxon test showed a significant improvement in segmental kyphosis in the postoperative period $(p<.000)$. (Tables 3,4$)$.

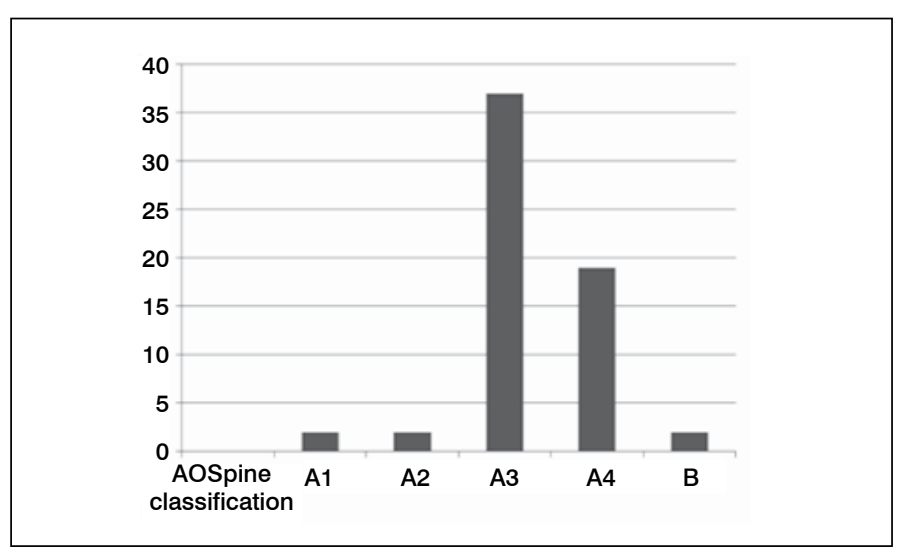

Figure 4. Distribution of the fractures by AOSpine classification.

Table 1. Average of the parameters analyzed for the total number of patients, quantity and percentage of the total by parameter that fall within those established in the literature.

\begin{tabular}{c|c|c|c}
\hline Parameters & $\begin{array}{c}\text { Average Total } \\
\text { (63) }\end{array}$ & $\begin{array}{c}\text { \# within the } \\
\text { parameters }\end{array}$ & $\begin{array}{c}\text { \% within the } \\
\text { parameters }\end{array}$ \\
\hline Pelvic incidence & $47.5^{\circ}$ & 55 & 87 \\
\hline Pelvic tilt & $13.8^{\circ}$ & 52 & 83 \\
\hline Sacral slope & $34^{\circ}$ & 60 & 95 \\
\hline Lumbar lordosis & $48^{\circ}$ & 46 & 73 \\
\hline L4-S1 lordosis & $37.6^{\circ}$ & 38 & 60 \\
\hline Preop seg. kyphosis & $-8.8^{\circ}$ & $\mathrm{NA}$ & $\mathrm{NA}$ \\
\hline Postop seg. kyphosis & $0.4^{\circ}$ & $\mathrm{NA}$ & $\mathrm{NA}$ \\
\hline VAS at discharge & 1.82 & $\mathrm{NA}$ & $\mathrm{NA}$
\end{tabular}

Table 2. Average of the parameters analyzed in the patients by vertebra fractured and by AOSPINE severity classification.

\begin{tabular}{|c|c|c|c|c|c|c|c|c|c|c|}
\hline Parameters & $\begin{array}{l}A 1 \\
(2)\end{array}$ & $\begin{array}{l}\text { A2 } \\
\text { (2) }\end{array}$ & $\begin{array}{c}\text { A3 } \\
\text { (38) }\end{array}$ & $\begin{array}{c}\text { A4 } \\
\text { (19) }\end{array}$ & $\begin{array}{c}B \\
(2)\end{array}$ & $\begin{array}{c}\text { L1 } \\
\text { (30) }\end{array}$ & \begin{tabular}{|c} 
L2 \\
(19)
\end{tabular} & \begin{tabular}{|c|} 
L3 \\
(10)
\end{tabular} & $\begin{array}{l}\text { L4 } \\
\text { (3) }\end{array}$ & $\begin{array}{l}\text { L5 } \\
\text { (1) }\end{array}$ \\
\hline Pelvic incidence & 47 & 45 & 48 & 45 & 58 & 48 & 49.5 & 42.8 & 47.3 & 37 \\
\hline Pelvic tilt & 10.5 & 10 & 15 & 13 & 10.5 & 14.6 & 15 & 10.8 & 7.6 & 14 \\
\hline Sacral slope & 36.5 & 35.5 & 33 & 32 & 47.5 & 33.3 & 34 & 32 & 39 & 23 \\
\hline Lumbar lordosis & 49 & 48.5 & 48 & 46.6 & 59.5 & 49.5 & 47.8 & 44.4 & 52 & 28 \\
\hline L4-S1 lordosis & 40 & 29.5 & 37.5 & 37.8 & 42 & 39.3 & 38.6 & 32.6 & 36.6 & 20 \\
\hline $\begin{array}{c}\text { PreOp seg. } \\
\text { kyphosis }\end{array}$ & -5.5 & -8 & -10 & -9 & 8.7 & -14 & -8 & -3.9 & 11.3 & 14 \\
\hline $\begin{array}{c}\text { PostOp seg. } \\
\text { kyphosis }\end{array}$ & -0.7 & 8.3 & -0.4 & 0.4 & 9.9 & -4.5 & 0.8 & 7.4 & 17 & 15.4 \\
\hline VAS at discharge & 0.5 & 2 & 1.8 & 1.9 & 2 & 1.9 & 1.3 & 1.9 & 3 & 3 \\
\hline
\end{tabular}


Table 3. Statistical analysis using Pearson's correlation coefficient test for the different variables. $(F X=f r a c t u r e, p t=p e l v i c$ tilt, $s S=s a c r a l ~ s l o p e$, cspost=postoperative segmental kyphosis, II=lumbar lordosis, PI-LL=pelvic incidence-lumbar lordosis, I4-s1=L4-S1 lumbar lordosis, VAS=visual analog scale, $F x=A O$ classification, Sig. (significance) = "p").

\begin{tabular}{|c|c|c|c|c|c|c|c|c|c|c|c|}
\hline \multicolumn{12}{|c|}{ Correlations } \\
\hline & & Age & Level & FX & cspost & pt & ss & II & PI-LL & 14 s 1 & VAS \\
\hline \multirow{3}{*}{ Age } & pearson Correlation & 1 & -.085 & .170 & .020 & -.003 & $.286^{*}$ & $.333^{* *}$ & -.021 & $.320^{*}$ & -.013 \\
\hline & Sig. (2-tailed) & & .506 & .183 & .877 & .982 & .023 & .008 & .869 & .011 & .920 \\
\hline & $\mathrm{N}$ & 63 & 63 & 63 & 63 & 63 & 63 & 63 & 63 & 63 & 63 \\
\hline \multirow{3}{*}{ Level } & pearson Correlation & -.085 & 1 & .159 & $.688^{* *}$ & -.200 & -.007 & -.136 & .024 & -.240 & .071 \\
\hline & Sig. (2-tailed) & .506 & & .213 & .000 & .116 & .958 & .287 & .850 & .059 & .580 \\
\hline & $\mathrm{N}$ & 63 & 63 & 63 & 63 & 63 & 63 & 63 & 63 & 63 & 63 \\
\hline \multirow{3}{*}{ FX } & Pearson Correlation & .170 & .159 & 1 & .069 & -.041 & .040 & .036 & .006 & .070 & .100 \\
\hline & Sig. (2-tailed) & .183 & .213 & & .591 & .751 & .758 & .777 & .962 & .584 & .436 \\
\hline & $N$ & 63 & 63 & 63 & 63 & 63 & 63 & 63 & 63 & 63 & 63 \\
\hline \multirow{3}{*}{ cspost } & Pearson Correlation & .020 & $.688^{* *}$ & .069 & 1 & -.048 & .134 & .094 & .085 & $-.341^{* *}$ & .065 \\
\hline & Sig. (2-tailed) & .877 & .000 & .591 & & .707 & .295 & .465 & .507 & .006 & .614 \\
\hline & $\mathrm{N}$ & 63 & 63 & 63 & 63 & 63 & 63 & 63 & 63 & 63 & 63 \\
\hline \multirow{3}{*}{ pt } & Pearson Correlation & -.003 & -.200 & -.041 & -.048 & 1 & .018 & $.377^{* *}$ & -.056 & .244 & .059 \\
\hline & Sig. (2-tailed) & .982 & .116 & .751 & .707 & & .890 & .002 & .661 & .054 & .647 \\
\hline & $N$ & 63 & 63 & 63 & 63 & 63 & 63 & 63 & 63 & 63 & 63 \\
\hline \multirow{3}{*}{ ss } & Pearson Correlation & $286^{*}$ & -.007 & .040 & .134 & .018 & 1 & $.630^{* *}$ & -.009 & $.380^{* *}$ & -.075 \\
\hline & Sig. (2-tailed) & .023 & .958 & .758 & .295 & .890 & & .000 & .944 & .002 & .560 \\
\hline & $\mathrm{N}$ & 63 & 63 & 63 & 63 & 63 & 63 & 63 & 63 & 63 & 63 \\
\hline \multirow{3}{*}{$\|$} & Pearson Correlation & $.333^{* *}$ & -.136 & .036 & .094 & $.377^{* *}$ & $.630^{* *}$ & 1 & .093 & $.758^{* *}$ & .023 \\
\hline & Sig. (2-tailed) & .008 & .287 & .777 & .465 & .002 & .000 & & .471 & .000 & .861 \\
\hline & $\mathrm{N}$ & 63 & 63 & 63 & 63 & 63 & 63 & 63 & 63 & 63 & 63 \\
\hline \multirow{3}{*}{ PI-LL } & Pearson Correlation & -.021 & .024 & .006 & .085 & -.056 & -.009 & .093 & 1 & -.031 & .026 \\
\hline & Sig. (2-tailed) & .869 & .850 & .962 & .507 & .661 & .944 & .471 & & .808 & .839 \\
\hline & $\mathrm{N}$ & 63 & 63 & 63 & 63 & 63 & 63 & 63 & 63 & 63 & 63 \\
\hline \multirow{3}{*}{14 s1 } & Pearson Correlation & $.320^{*}$ & -.240 & .070 & $-.341^{* *}$ & .244 & $.380^{* *}$ & $.758^{* *}$ & -.031 & 1 & .011 \\
\hline & Sig. (2-tailed) & .011 & .059 & .584 & .006 & .054 & .002 & .000 & .808 & & .932 \\
\hline & $\mathrm{N}$ & 63 & 63 & 63 & 63 & 63 & 63 & 63 & 63 & 63 & 63 \\
\hline \multirow{3}{*}{ VAS } & Pearson Correlation & -.013 & .071 & .100 & .065 & .059 & -.075 & .023 & .026 & .011 & 1 \\
\hline & Sig. (2-tailed) & .920 & .580 & .436 & .614 & .647 & .560 & .861 & .839 & .932 & \\
\hline & $\mathrm{N}$ & 63 & 63 & 63 & 63 & 63 & 63 & 63 & 63 & 63 & 63 \\
\hline
\end{tabular}

*. Correlation is significant at the 0.05 level (2-tailed). ${ }^{\star *}$. Correlation is significant at the 0.01 level (2-tailed).

Table 4. Statistical Analysis of the Wilcoxon ranks of pre- and postoperative correction of the segmental kyphosis of the fracture.

\begin{tabular}{c|c}
\hline \multicolumn{2}{|c}{ Test statistics $^{\text {a }}$} \\
\hline Z & cspost - cspre $^{2}$ \\
\hline Asymp. Sig. (2-tailed) & $-6.884^{\mathrm{b}}$ \\
\hline
\end{tabular}

a. Wilcoxon signed ranks test. b. Based on negative ranks.

\section{DISCUSSION}

In recent years, sagittal balance has gained relevance and its study has become essential in chronic spine pathologies, especially those associated with deformities. It seems logical to think that there is no strong relationship between acute spinal deformities caused by trauma and the short-term consequences of sagittal imbalance, however, there are not many studies that define such relationships. Although our study did not evaluate patients over a long period of time to determine whether altered sagittal balance will actually produce a pain syndrome or accelerated degeneration, it allowed us to evaluated which factors may be associated with changes in sagittal balance. However, our results did not show strong correlation, that could be considered statistically significant, between the parameters that suggest sagittal imbalance and the other parameters of the patient and the fracture.

The balance parameters of most patients fall with the normal ranges, especially those related to the position of the pelvis. Lumbar lordosis presented a lower frequency of normality, having a tendency towards hypolordosis, although in some cases apparently normal in terms of its relationship to pelvic incidence. It is important to comment on the fact that pelvic incidence, despite being a fixed parameter, is variable in our study population (Mexican), and, even so, the distribution is comparable to those reported in the international literature.

Contrary to what one would think, lumbar lordosis had an almost neutral relationship with final segmental kyphosis. Even the patients with greater residual segmental kyphosis were found to have lordosis within the normal parameters and also in relation to pelvic incidence. Age was more highly correlated with lordosis and sacral slope: the greater the age, the greater the lordosis and the sacral slope. However, the test did not show statistical significance. In addition, the patients with sagittal balance outside of the normal parameters were not in greater pain than those who fell within the normal parameter range.

All the patients had postoperative segmental kyphosis greater than $-13^{\circ}$; five of them had segmental kyphosis $>20^{\circ}$ prior to surgery. Posterior instrumentation permitted a reduction of the deformity reaching acceptable values. ${ }^{9}$

There are many publications that talk about the superiority of transpedicular systems with Schantz nails and monoaxial screws over polyaxial transpedicle screws in the management of fractures, especially because of the ease and the quality of the segmental reduction. However, it is worth noting that, in general, the results of segmental reduction with the polyaxial system used in our series are trending towards improvement $(p<.000) .{ }^{12}$ 


\section{CONCLUSION}

Management with posterior instrumentation with a polyaxial system permits adequate correction in most patients. Segmental kyphosis was adequately reduced in most patients and No patients met criterias for diagnosis of Posttraumatic Kyphosis.

Most of the patients evolved with tolerable discomforts and few of them evolved with persistent pain. In the patients with residual pain, the factors of sagittal balance and the type and level of the fracture did not seem to have a significant effect. Because of the insignificance correlation found, it would be inadvisable to assign the residual pain to the mechanical balance parameters related to the fracture. However, we cannot rule out the possibility that sagittal imbalance could have long-term repercussions.

Most of the patients had sagittal balance parameters within normality. However, where there was a greater change in sagittal balance was among the parameters related to lordosis, but no significant relationship with the characteristics of the fracture was found.

All authors declare no potential conflict of interest related to this article.

CONTRIBUTION OF THE AUTHORS: Each author made significant individual contributions to this article. LML (0000-0003-2363-5589) and FGV (0000-0001-8831-1767)* were the main contributors to the preparation of the manuscript. JESO (0000-0001-8009-2432)* and OICC (0000-0003-44060024)* conducted patient follow-up and collected clinical surgical data. LML and FGV evaluated the analysis data. FGV performed the bibliographical research, data collection, project status reporting, and prepared the final manuscript. LML conducted the review and final approval of the manuscript and contributed to the intellectual concept of the study. ${ }^{*} \mathrm{ORCID}$ (Open Researcher and Contributor ID).

\section{REFERENCES}

1. Le Huec JC, Roussouly P. Sagittal spino-pelvic balance is a crucial analysis for normal and degenerative spine. Eur Spine J. 2011;20(Suppl 5):556-7.

2. Glassman SD, Bridwell K, Dimar JR, Horton W, et al. The impact of positive sagittal balance on adult spinal deformity. Spine (Phila Pa 1976). 2005;30 (18):2024-9.

3. Kepler CK, Vaccaro AR, Schroeder GD, Koerner JD, Vialle LR, Aarabi B, et al. The Thoracolumbar AOSpine Injury Score. Global Spine J. 2016;6(4):329-34.

4. Kim BG, Dan JM, Shin DE. Treatment of thoracolumbar fracture. Asian Spine J. 2015;9(1):133-46.

5. Roussouly P, Nnadi C. Sagittal plane deformity: an overview of interpretation and management. Eur Spine J. 2010;19:1824-36.

6. Lamartina C, Berjano P. Classification of sagittal imbalance based on spinal alignment and compensatory mechanisms. Eur Spine J. 2014;23(6):1177-89.

7. Tejeda M. Balance Sagital en columna vertebral. Su significado e importancia. Ortho-tips. 2015;11(3): 115-20
8. Muñiz LL, Sámano HV, Heredia MM, et al. Discapacidad Funcional, Alineación Sagital y Balance Pélvico en Espondilolistesis Lumbar. Coluna/Columa. 2016;15(1):30-2.

9. Boissière L,Bourghli $A$, Vital JM, Gille O,Obeid I. The lumbar lordosis index: a new ratio to detect spinal malalignment with a therapeutic impact for sagittal balance correction decisions in adult scoliosis surgery. Eur Spine J. 2013 22(6):1339-45.

10. Munting E. Surgical treatment of post-traumatic kyphosis in the thoracolumbar spine: indications and technical aspects. Eur Spine J. 2010;19(Suppl 1):69-73.

11. Mayer M, Ortmaier R, Koller H, Koller J, Hitzl W, Auffarth A, et al. Impact of Sagittal Balance on Clinical Outcomes in Surgically Treated T12 and L1 Burst Fractures: Analysis of Long-Term Outcomes after Posterior-Only and Combined PosteroanteriorTreatment. Biomed Res Int. 2017;1568258.

12. Wang H, Li C, Liu T, Zhao WD, Zhou Y. Biomechanical efficacy of monoaxial or polyaxial pedicle screw and additional screw insertion at the level of fracture, in lumbar burst fracture: An experimental study. Indian J Orthop. 2012;46(4): 395-401. 